ISSN 1392-3196 / e-ISSN 2335-8947

Zemdirbyste-Agriculture, vol. 105, No. 3 (2018), p. 227-234

DOI 10.13080/z-a.2018.105.029

\title{
The effect of a growth regulator Ribav-Extra on winter wheat seedlings exposed to heavy metals
}

\author{
Kristina A. GRUZNOVA ${ }^{1}$, Dmitry I. BASHMAKOV ${ }^{1}$, Jurga MILIAUSKIENE ${ }^{2}$, \\ Viktorija VAŠTAKAITÉ ${ }^{2}$, Pavelas DUCHOVSKIS ${ }^{2,3}$, Alexander S. LUKATKIN ${ }^{1}$ \\ ${ }^{1}$ National Research Mordovia State University \\ Bolshevistskaja 68, 430005 Saransk, Russia \\ ${ }^{2}$ Institute of Horticulture, Lithuanian Research Centre for Agriculture and Forestry \\ Kauno 30, Babtai, Kaunas distr., Lithuania \\ E-mail: p.duchovskis@1sdi.lt \\ ${ }^{3}$ Aleksandras Stulginskis University \\ Studentų 15A, Akademija, Kaunas distr., Lithuania
}

\begin{abstract}
We studied the influence of a natural plant growth regulator Ribav-Extra and ions of heavy metals (HM) $\mathrm{Pb}^{2+}, \mathrm{Cu}^{2+}$, $\mathrm{Zn}^{2+}$ and $\mathrm{Ni}^{2+}$ on the physiological and biochemical indices of the winter wheat (Triticum aestivum L. ) cultivar 'Mironovskaya 808'. The seeds of wheat were treated with Ribav-Extra (10 ppm) and grown for 7 days on heavy metal salt solutions $(10 \mu \mathrm{M}$ or $1 \mathrm{mM})$. After that we recorded heavy metals accumulation, growth, generation of superoxide anion $\left({ }^{\circ} \mathrm{O}_{2}^{-}\right.$), lipid peroxidation (LPO), and catalase (CAT) and ascorbate peroxidase (APOX) activity. It was found that $1 \mathrm{mM}$ of HM in growth media increased heavy metals accumulation in wheat plants and inhibited the growth of roots and shoots. Both low and high concentrations of heavy metals stimulated ${ }^{\circ} \mathrm{O}_{2}{ }^{-}$production and oxidative damage in wheat seedlings. In most treatments, the toxic effect of heavy metals enhanced at higher concentration of metals. Pre-sowing treatment of seeds with Ribav-Extra decreased the negative impact of heavy metals by reducing oxidative stress which led to suppressed ${ }^{\circ} \mathrm{O}_{2}^{-}$generation, lipid peroxidation intensity and catalase activity. This suggests that the wheat plants, whose seeds had been treated with Ribav-Extra, were more heavy metal-resistant than the untreated ones.
\end{abstract}

Key words: antioxidative enzymes, heavy metals, oxidative stress, Ribav-Extra, Triticum aestivum.

\section{Introduction}

Soil contamination with various heavy metals and their impacts on plant health and productivity are extensively reported (Anjum et al., 2015 a). Once inside plants, even low levels of heavy metals are phytotoxic. In plants, heavy metals cause various disorders in physiological and metabolic processes. They can impair plant growth, development and productivity (Duchovskis et al., 2006; Башмаков, Лукаткин, 2009; Gangwar et al., 2014; Anjum et al., 2015 a). Elevation in the generation of reactive oxygen species (ROS), such as superoxide radicals $\left({ }^{\circ} \mathrm{O}_{2}^{-}\right)$, hydroxyl radicals $\left(\mathrm{OH}^{*}\right)$, perhydroxyl radicals $\left(\mathrm{HO}_{2}^{\circ}\right)$, alkoxy radicals $\left(\mathrm{RO}^{\circ}\right)$, hydrogen peroxide $\left(\mathrm{H}_{2} \mathrm{O}_{2}\right)$ and singlet oxygen $\left({ }^{1} \mathrm{O}_{2}\right)$, has been considered as the major factor of plant response to low and high levels of beneficial metals (Hossain et al., 2012; Anjum et al., 2015 a). Notably, if not metabolized, ROS can imbalance cellular redox homeostasis and oxidize lipids and proteins (Anjum et al., $2015 \mathrm{~b}$ ), and finally halt cellular metabolism (Anjum et al., 2012). Plants tend to counteract ROS-accrued consequences by employing antioxidant defence system comprising antioxidative enzymes, such as superoxide dismutase (SOD), catalase (CAT), ascorbate peroxidase (APOX) and glutathione reductase (GR), and non-enzymatic antioxidants, such as ascorbate, glutathione, tocopherol, carotenoids and flavonoids (Anjum et al., 2012; 2016). Toxic effects of heavy metals strongly depend on the metal, its concentration, plant species and plant phenophase as well as on the environmental (edaphic, climatic, etc.) factors (Sharma et al., 2017).

Modern agriculture seeks to achieve the maximum productivity of agricultural plants and to obtain a yield that does not contain substances toxic to humans and animals (Lazauskas et al., 2012). Bioactive compounds are extensively reported to confer tolerance to environmental stresses in plants (Asgher et al., 2015; Miliauskienè et al., 2016). Thus, exogenous application of plant growth regulators (PGRs) can significantly

Please use the following format when citing the article:

Gruznova K. A., Bashmakov D. I., Miliauskienė J., Vaštakaitė V., Duchovskis P., Lukatkin A. S. 2018. The effect of a growth regulator Ribav-Extra on winter wheat seedlings exposed to heavy metals. Zemdirbyste-Agriculture, 105 (3): $227-234$ DOI $10.13080 / \mathrm{z}-\mathrm{a} .2018 .105 .029$ 
modulate both enzymatic and non-enzymatic components of the antioxidant defence system, neutralize the negative impact of heavy metals such as alterations in the activity of enzymes of radical scavenging system, and are capable of improving plant growth or/and biomass accumulation, chlorophyll and carotenoid content, the rate of photosynthesis, heavy metals accumulation in yield, etc. (Bashmakov et al., 2012; Gangwar et al., 2014; Asgher et al., 2015; Xia et al., 2015, Gruznova et al., 2017).

Synthetic PGRs like brassinosteroids (Fariduddin et al., 2013; Hayat et al., 2014; Bashmakov et al., 2016), cytokinin-like substances (Bashmakov et al., 2012; Sazanova et al., 2012), exogenous gibberellins (Gangwar et al., 2011 a), synthetic auxins (Gangwar et al., 2011 b; Zhu et al., 2013), salicylic acid (Zhang et al., 2011; Ali et al., 2015) or methyl jasmonate (Singh, Shah, 2014) are used as protectors against stress induced in plants by heavy metals.

Natural growth regulators are a complex of bioactive compounds of plant origin or products of the metabolism of microorganisms. They can be used in low concentrations and are non-toxic to plants and to the environment. The application of some natural products to plants showed plants resistance to biotic (Sakalauskienè et al., 2012), abiotic stresses (Lukatkin, Pogodina, 2012), heavy metals and herbicides (Asgher et al., 2015).

A natural plant growth regulator Ribav-Extra ${ }^{\circledR}$ is a product of the metabolism of mycorrhizal fungi isolated from ginseng (Panax ginseng C.A. Мey) roots (Рязин и др., 2005; Толмачева, Михеева, 2008). It stimulates the synthesis of phytohormones, growth processes, and it can increase resistance to stressors (Толмачева, Михеева, 2008). Earlier it was shown that Ribav-Extra increased plant tolerance to temperature stress (Lukatkin, Pogodina, 2012). Currently, studies on the effect of Ribav-Extra on the crop plants are extremely few; therefore, the study on the effectiveness of Ribav-Extra application on medium containing heavy metals is of practical interest.

This study aimed to evaluate the significance of Ribav-Extra in the control of growth traits, ${ }^{\circ} \mathrm{O}_{2}^{-}$level, lipid peroxidation intensity, CAT and APOX activity, heavy metals tolerance and accumulation in winter wheat under $\mathrm{Cu}^{2+}, \mathrm{Ni}^{2+}, \mathrm{Zn}^{2+}$ and $\mathrm{Pb}^{2+}$ exposure. Hence, this study investigated the physiological and biochemical efficacy of pre-sowing seed treatment with Ribav-Extra solutions.

\section{Materials and methods}

Plant culture. Commercial seeds of the winter wheat (Triticum aestivum L.) subspecies lutescens cultivar 'Mironovskaya 808' were used for this experiment.

Plant growth regulator. A natural plant growth regulator Ribav-Extra ${ }^{\circledR}$ ("Selhozekoservis", Russia) is a product of the metabolism of mycorrhizal fungi isolated from ginseng (Panax ginseng C.A. Mey) roots. RibavExtra (RE) is a $60 \%$ alcohol extract, which contains a complex of natural amino acids and biological active substrates. Ribav-Extra is usually used in field or greenhouses for seed treatment, spraying plants or processing cuttings. It stimulates plant resistance to unfavourable environment (Толмачева, Михеева, 2008).

Heavy metals (HM) exposure. Wheat seeds were treated with $0.5 \% \mathrm{KMnO}_{4}$ for 5 min to surface sterilize then with 10 ppm Ribav-Extra for $8 \mathrm{~h}$ (control seeds were treated with distilled water), and then germinated in plastic pots (50 seeds per pot) for 7 days in water (50 ml per pot) supplemented with $10 \mu \mathrm{M}$ (low dose) or $1 \mathrm{mM}$ (high dose) $\mathrm{Pb}\left(\mathrm{NO}_{3}\right)_{2}$, or $\mathrm{CuSO}_{4} \times 5 \mathrm{H}_{2} \mathrm{O}$, or $\mathrm{NiSO}_{4}$ $\times 7 \mathrm{H}_{2} \mathrm{O}$ or $\mathrm{ZnSO}_{4} \times 7 \mathrm{H}_{2} \mathrm{O}$, at temperature $22-24^{\circ} \mathrm{C}$, photoperiod 16/8 $\mathrm{h}$ (day/night), and the photosynthetic photon flux density (PPFD) was about $80 \mu \mathrm{mol} \mathrm{m} \mathrm{m}^{-2} \mathrm{~s}^{-1}$. In 7 -day seedlings we measured heavy metals accumulation in shoots and roots, length of axial organs, superoxide $\left({ }^{\circ} \mathrm{O}_{2}^{-}\right)$generation in leaves, lipid peroxidation (LPO) intensity, and catalase (CAT) and ascorbate peroxidase (APOX) activities.

Biometric measurments. The length of axial organs in 30 selected seedlings per single experiment was measured. To assess the tolerance of seedlings to heavy metals we applied a Wilkins tolerance index (WTI):

$\mathrm{WTI}=\left(l_{m e} / l_{c}\right) \times 100 \%$, where $l_{m e}$ is the root length in a metal ion solution, $l_{c}$ - the root length in the control material (Wilkins, 1978).

Heavy metals accumulation in biomass was determined using atomic absorbance spectrometer AA7000 (Shimadzu, Japan). The heavy metals content in plant samples was calculated in $\mu \mathrm{g} \mathrm{g}^{-1}$ of air-dry weight (Bashmakov et al., 2015). To assess the heavy metals transition in aerial parts, we used an index of the metal translocation $\left(\mathrm{I}_{\mathrm{HMt}}\right)$ :

$\mathrm{I}_{\mathrm{HMt}}=\left(\mathrm{C}_{\mathrm{s}} / \mathrm{C}_{\mathrm{r}}\right)$, where $\mathrm{C}_{\mathrm{s}}$ is the metal concentration in the shoots, $\mathrm{C}_{\mathrm{r}}$ - the metal concentration in the roots.

Superoxide $\left(\mathrm{O}_{2}^{-}\right)$generation in leaf disks was detected using a method that is based on the capacity of $\mathrm{O}_{2}{ }^{-}$to oxidize epinephrine to adrenochrome (Lukatkin, $2002 \mathrm{a}$ ). A total of $300 \mathrm{mg}$ of leaves was homogenized with $15 \mathrm{ml}$ of distilled water. The solution was centrifuged for $15 \mathrm{~min}$ at $3000 \mathrm{rpm}$; $0.1 \mathrm{ml}$ of adrenaline solution $(0.01 \%)$ was added to $3 \mathrm{ml}$ of homogenate and incubated for $45 \mathrm{~min}$ at ambient temperature and $200 \mu \mathrm{M}$ photons $\mathrm{m}^{-2} \mathrm{~s}^{-1}$. Immediately after incubation, the optical density of the adrenochrome that formed was measured against homogenate in water on a spectrophotometer UVmini 1240 (Shimadzu, Japan) at $\lambda=480 \mathrm{~nm}$. The rate of ${ }^{\circ} \mathrm{O}_{2}{ }^{-}$ generation was calculated by adopting a molar extinction coefficient $\left(\varepsilon=4020 \mathrm{M}^{-1} \mathrm{~cm}^{-1}\right)$ in $\mu \mathrm{M} \mathrm{g}^{-1} \mathrm{~min}^{-1}$.

Lipid peroxidation (LPO) intensity in leaf disks was detected using a method that is based on the accumulation of malonic dialdehyde (MDA) (Lukatkin, $2002 \mathrm{a}$ ). A total of $300 \mathrm{mg}$ of leaves was homogenized with $10 \mathrm{ml}$ of medium containing $0.1 \mathrm{M}$ Tris- $\mathrm{HCl}$ buffer, pH 7.6, with $0.35 \mathrm{M} \mathrm{NaCl}$. Two $\mathrm{ml}$ of thiobarbituric acid (TBA) in 20\% trichloroacetic acid (TCA) was added to $3 \mathrm{ml}$ of homogenate, heated in a boiling water bath for 30 minutes and filtered. The optical density was recorded against isolation medium on a spectrophotometer UV mini 1240 at $\lambda=532 \mathrm{~nm}$. The concentration of MDA was calculated by adopting a molar extinction coefficient $\left(\varepsilon=1.56 \times 10^{5} \mathrm{M}^{-1} \mathrm{~cm}^{-1}\right)$ in $\mu \mathrm{M} \mathrm{g}^{-1}$ of fresh leaves weight. Catalase (EC 1.11.1.6) activity detection. One $\mathrm{g}$ of leaf disks was homogenized with $10 \mathrm{ml}$ of $50 \mathrm{mM}$ phosphate buffer ( $\mathrm{pH}$ 7.0). The homogenate was filtered and centrifuged for $10 \mathrm{~min}$ at $8000 \times \mathrm{g} ; 2.9 \mathrm{ml}$ of phosphate buffer ( $\mathrm{pH} 7.0$ ) was added to $25 \mu$ l of enzyme extract. Directly before the measurement, $90 \mu \mathrm{l}$ of $3 \%$ hydrogen peroxide $\left(\mathrm{H}_{2} \mathrm{O}_{2}\right)$ was added to the solution. The optical density decrease during $1 \mathrm{~min}$ was measured on a spectrophotometer UV mini 1240 at $\lambda=240 \mathrm{~nm}$. The activity of CAT was calculated by adopting a molar 
extinction coefficient $\left(\varepsilon=39.4 \mathrm{mM}^{-1} \mathrm{~cm}^{-1}\right)$ in $\mu \mathrm{M} \mathrm{g}^{-1} \mathrm{~min}^{-1}$ (Lukatkin, 2002 b).

Ascorbate peroxidase (EC 1.11.1.11) activity detection. One $\mathrm{g}$ of leaf disks was homogenized with

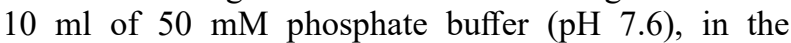
cold. Polyvinylpyrrolidone $(0.3 \mathrm{~g})$ was added to the homogenate, which was filtered and then centrifuged for $10 \mathrm{~min}$ at $12000 \times \mathrm{g}$. The reaction mixture contained $50 \mu \mathrm{l}$ of $0.1 \mathrm{mM}$ ethylenediaminetetraacetic acid (EDTA), 50 $\mu 1$ of $0.05 \mathrm{mM}$ ascorbate (AsA), $50 \mu \mathrm{l}$ of $0.1 \mathrm{mM} \mathrm{H}_{2} \mathrm{O}_{2}$, $2.55 \mathrm{ml}$ of $50 \mathrm{mM}$ phosphate buffer (pH 7.6) and $300 \mu \mathrm{l}$ of plant extract, which was obtained after centrifugation of the homogenate. The optical density was measured on a spectrophotometer UVmini 1240 at $\lambda=290 \mathrm{~nm}$ against the control mixture devoid of the enzyme extract. The contribution of nonenzymatic AsA oxidation was neglected, since it did not exceed 5\%. A decrease in the optical density for the first $30 \mathrm{~s}$ of the reaction was taken as a measure of the enzyme activity, which was expressed in $\mu \mathrm{M}$ AsA g ${ }^{-1} \mathrm{~min}^{-1}$ using a molar extinction coefficient $\left(\varepsilon=2.8 \mathrm{mM}^{-1} \mathrm{~cm}^{-1}\right)$ (Lukatkin, $\left.2002 \mathrm{~b}\right)$.
Statistical analysis. All experiments were conducted in triplicate, and each experiment consisted of at least 150 seedlings. For all measurements averages and standard errors were calculated in MS Excel. Differences between means were assessed by the Duncan's test at $P=0.05$.

\section{Results and discussion}

Accumulation of heavy metals in the axial organs of winter wheat. Heavy metals are toxic to plants in high doses (Anjum et al., 2015 a). Due to the fact that only absorbed metal ions can affect plants, it is necessary to determine the accumulation of heavy metals in various organs of the plants. The concentration of metals in the roots and shoots of wheat was determined 7 days after exposure of plants to heavy metals. In the control plants, the heavy metal concentrations were very low, probably indicating the initial content of heavy metals in the seeds. The heavy metal-treated plants exhibited much higher contents of heavy metals as compared to the control plants (Table 1).

Table 1. The influence of Ribav-Extra (RE) on the metal accumulation ( $\left.\mu \mathrm{g} \mathrm{g}^{-1} \mathrm{DM}\right)$ and translocation in winter wheat plants treated with heavy metal (HM) ions

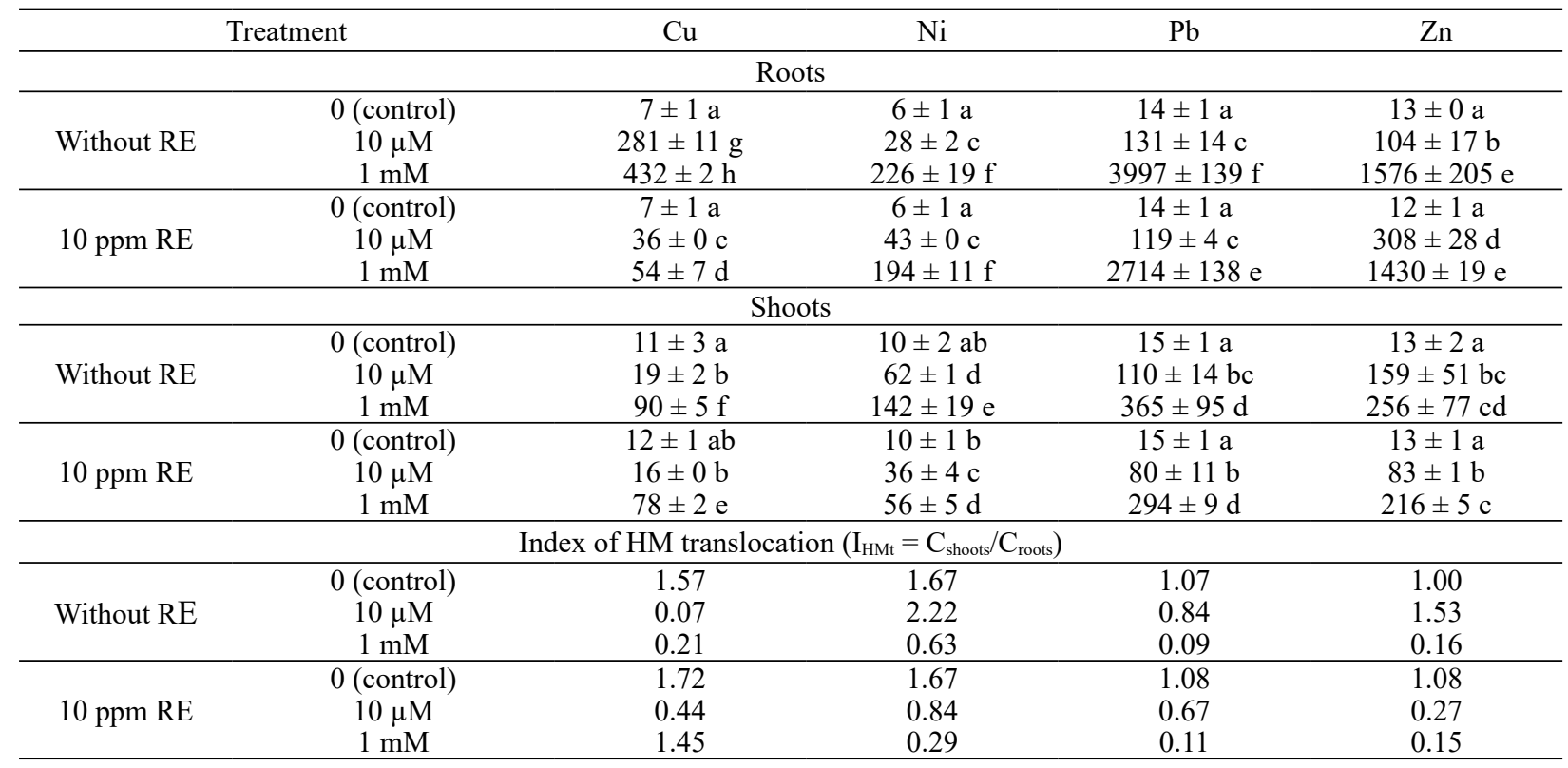

Note. Different letters within each column mean significant differences between treatments (assessed by the Duncan's test at $P=0.05$ ).

Higher concentrations of heavy metals in solutions resulted in higher accumulation of metals in the wheat seedlings. However, in the roots of plants exposed to $10 \mu \mathrm{M}$, metal concentrations increased from 4.6 to 40 times (in the sequence $\mathrm{Ni}<\mathrm{Zn} \approx \mathrm{Pb}<<\mathrm{Cu}$ ), and in shoots up to 12.2 times (in the sequence $\mathrm{Cu}<\mathrm{Ni} \approx \mathrm{Pb}<$ $\mathrm{Zn}$ ). When the heavy metals concentrations in the growth medium were maximal ( $1 \mathrm{mM})$, the metal concentrations increased even more: from 37.6 to 277 times (in the sequence $\mathrm{Ni}<\mathrm{Cu}<\mathrm{Zn}<\mathrm{Pb})$ in the roots and from 8.2 to 24.3 times (in the sequence $\mathrm{Cu}<\mathrm{Ni}<\mathrm{Zn}<\mathrm{Pb}$ ) in the shoots.

We found that the metal concentrations in the aerial biomass were lower than those in the roots (except for $10 \mu \mathrm{M} \mathrm{Ni}^{2+}$ ). The ability of the roots to bind heavy metals reduces their translocation to the aerial organs (Sharma et al., 2017). At the same time, it was established that the number of heavy metals in stems and leaves increases with an increase in the metal concentration in the environment and with an increase in their content in the roots. This indicates that protective mechanisms and barriers at root cell and tissue levels are not able to completely prevent the heavy metals translocation into shoots (Seregin, Kozhevnikova, 2008).

Index of heavy metals translocation $\left(\mathrm{I}_{\mathrm{HMt}}\right)$ showed that at low concentration it was small in the case of $\mathrm{Cu}^{2+}$, but exceed 1 in treatments with $\mathrm{Ni}^{2+}$ and $\mathrm{Zn}^{2+}$. Higher concentration of heavy metals led to sharp diminution of heavy metals translocation (except $\mathrm{Cu}^{2+}$ ). Presowing treatment with Ribav-Extra modified both the heavy metals uptake into the roots and heavy metals translocation into shoots significantly. Thus, in the medium containing $10 \mu \mathrm{M} \mathrm{Ni}{ }^{2+}$ or $\mathrm{Zn}^{2+}$, RibavExtra enhanced the ion uptake into the roots by 1.5 or 3 times, respectively; but it reduced significantly the $\mathrm{Cu}^{2+}$ uptake, most in the medium containing $1 \mathrm{mM}$ 
HM ions. In the shoots of RE-pre-treated plants, heavy metal concentrations reduced from $14 \%$ to $59 \%$ against untreated plants. However, as a rule, the efficiency of the regulator decreased slightly as the concentration of heavy metals in the medium increased. Moreover, in all treatments of the experiment Ribav-Extra significantly increased (almost by 7 times) the roots to shoots transport of $\mathrm{Cu}$, but lowered Ni transport from root shoots, as was shown by $\mathrm{I}_{\mathrm{HMt}}$. In the case of $\mathrm{Pb}$ and $\mathrm{Zn}$, the $\mathrm{I}_{\mathrm{HMt}}$ level was invariable in wheat seedlings pre-treated with RibavExtra (Table 1).

The influence of heavy metal ions and RibavExtra on winter wheat seedling growth. Growth is an integral characteristic of the plant state, indicating disturbances in physiological processes at the organism level. Disturbances in growth and morphogenesis are visible symptoms of plant exposure to stress factors. Also, the heavy metals toxicity can be clearly traced on growth inhibition, as shown for a wide range of plant species (Wilkins, 1978; Gangwar et al., 2014; Singh et al., 2016; Hussain et al., 2017). In this experiment, we demonstrated the growth parameters of wheat plants exposed to heavy metal ions. Seven days after wheat seedlings exposure to $10 \mu \mathrm{M}$ of all HM ions (except for $\mathrm{Zn}^{2+}$ ), the root lengths exceeded those in water control plants by $25 \%$ to $38 \%$ (Table 2). One $\mathrm{mM}$ of $\mathrm{Ni}^{2+}, \mathrm{Cu}^{2+}$ and $\mathrm{Pb}^{2+}$ inhibited root growth significantly (by 92,70 and $40 \%$, respectively, in comparison to water control); $\mathrm{Zn}^{2+}$ both concentrations did not affect the root growth. Also, $10 \mu \mathrm{M} \mathrm{HM}$ (except for $\mathrm{Ni}^{2+}$ ) stimulated the growth of wheat shoots. When the plants were exposed to the higher concentration $(1 \mathrm{mM})$ of $\mathrm{Cu}, \mathrm{Ni}$ or $\mathrm{Pb}$, shoot growth was inhibited, especially at $\mathrm{Ni}$ exposure $(76 \%$ to water control). However, the growth of shoots was more resistant to heavy metals in comparison to roots.

Table 2. The influence of Ribav-Extra (RE) on root and shoot length (mm) of winter wheat plants exposed to heavy metal ions

\begin{tabular}{cccccc}
\hline \multirow{2}{*}{ Treatment } & \multicolumn{2}{c}{ Roots } & Shoots \\
\cline { 3 - 6 } & & without RE & $10 \mathrm{ppm} \mathrm{RE}$ & without RE & $10 \mathrm{ppm} \mathrm{RE}$ \\
\hline \multicolumn{2}{c}{ Control } & $33 \pm 3 \mathrm{e}$ & $99 \pm 2 \mathrm{j}$ & $90 \pm 3 \mathrm{e}$ & $154 \pm 4 \mathrm{i}$ \\
\multirow{2}{*}{$\mathrm{Cu}$} & $10 \mu \mathrm{M}$ & $45 \pm 4 \mathrm{f}$ & $82 \pm 2 \mathrm{~h}$ & $109 \pm 3 \mathrm{f}$ & $122 \pm 2 \mathrm{gh}$ \\
& $1 \mathrm{mM}$ & $10 \pm 2 \mathrm{~b}$ & $18 \pm 1 \mathrm{~cd}$ & $74 \pm 3 \mathrm{~d}$ & $44 \pm 2 \mathrm{~b}$ \\
\hline \multirow{2}{*}{$\mathrm{Ni}$} & $10 \mu \mathrm{M}$ & $46 \pm 2 \mathrm{f}$ & $88 \pm 3 \mathrm{hi}$ & $61 \pm 4 \mathrm{c}$ & $120 \pm 3 \mathrm{~g}$ \\
& $1 \mathrm{mM}$ & $3 \pm 0 \mathrm{a}$ & $17 \pm 0 \mathrm{c}$ & $21 \pm 2 \mathrm{a}$ & $86 \pm 2 \mathrm{e}$ \\
\hline \multirow{2}{*}{$\mathrm{Pb}$} & $10 \mu \mathrm{M}$ & $42 \pm 3 \mathrm{f}$ & $91 \pm 3 \mathrm{i}$ & $105 \pm 6 \mathrm{f}$ & $158 \pm 3 \mathrm{i}$ \\
& $1 \mathrm{mM}$ & $20 \pm 1 \mathrm{~d}$ & $55 \pm 2 \mathrm{~g}$ & $72 \pm 4 \mathrm{~cd}$ & $129 \pm 3 \mathrm{~h}$ \\
\hline \multirow{2}{*}{$\mathrm{Zn}$} & $10 \mu \mathrm{M}$ & $36 \pm 3 \mathrm{ef}$ & $80 \pm 3 \mathrm{~h}$ & $105 \pm 5 \mathrm{f}$ & $155 \pm 4 \mathrm{i}$ \\
& $1 \mathrm{mM}$ & $31 \pm 3 \mathrm{e}$ & $81 \pm 2 \mathrm{~h}$ & $89 \pm 8 \mathrm{de}$ & $135 \pm 2 \mathrm{~h}$ \\
\hline
\end{tabular}

Note. Different letters mean significant differences between variants (separately for roots and for shoots).

The addition of Ribav-Extra significantly increased the length of winter wheat roots and shoots (except for $1 \mathrm{mM} \mathrm{Cu}^{2+}$ and $\mathrm{Ni}^{2+}$ ) relative to water control (Table 2). Root growth in water (control seedlings) was enhanced by three times. When Ribav-Extra was applied in combination with heavy metals, the root length increased with respect to treatments without Ribav-Extra pre-treatment. Maximal growth increases were noted at $1 \mathrm{mM}$ of $\mathrm{Ni}^{2+}$ and $\mathrm{Pb}^{2+}$ (5.6 and 2.7 times, respectively). Seed treatment with Ribav-Extra stimulated growth of above-ground parts in all experimental treatments (except for $1 \mathrm{mM} \mathrm{Cu}^{2+}$ ). The treatment with Ribav-Extra increased shoot length by $1.5-4.1$ and by $1.1-1.9$ times (for $1 \mathrm{mM}$ and $10 \mu \mathrm{M}$ of HM, respectively), as compared to heavy metal treatments without growth regulator. As a result, Ribav-Extra treatment led to reduced negative effect of heavy metals on shoot growth. But in the case of $1 \mathrm{mM}$ of $\mathrm{Cu}^{2+}$ there was no effect of Ribav-Extra treatment, because of significant decreases in shoot length by $41 \%$. Since the roots first react to heavy metals concentration in soils, the Wilkins tolerance index (WTI) was calculated to assess the heavy metal-tolerance of seedlings (Fig.).

As can be seen from the Figure, wheat plant WTI was about the control level at $10 \mu \mathrm{M}$ of HM, but decreased by $8-92 \%$ at $1 \mathrm{mM}$ HM. This indicates the resistance of wheat plants to suboptimal concentrations and their sensitivity to sub-lethal concentrations of heavy metals. Pre-sowing Ribav-Extra treatment promoted an increase in WTI relative to water control and heavy metal-treated plants. Thus, Ribav-Extra contributed to a

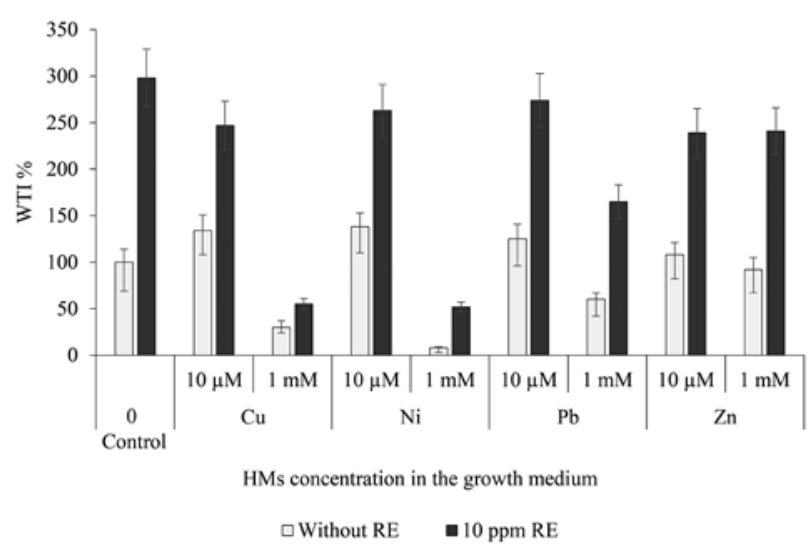

White columns - without Ribav-Extra (water or metal), black columns - metal + Ribav-Extra

Figure. The effect of Ribav-Extra (RE) on Wilkins tolerance index (WTI) in winter wheat seedlings treated with heavy metals (HM)

partial reduction or complete removal of the toxic effect of heavy metal ions.

The influence of heavy metal ions and RibavExtra on superoxide $\left(\mathrm{O}_{2}^{-}\right)$generation and lipid peroxidation (LPO) in winter wheat leaves. To assess the heavy metals toxicity, we studied the ${ }^{\circ} \mathrm{O}_{2}{ }^{-}$generation in plant cells exposed to stress environment (Mittler, 2002). It is known that the stress-induced increase in ${ }^{\circ} \mathrm{O}_{2}{ }^{-}$ generation is temporary, it was shown in plants exposed to both chilling (Lukatkin, 2002 a) and heavy metals 
(Lukatkin et al., 2010; Lehotai et al., 2011; Hossain et al., 2012; Thakur et al., 2017). We found that chronic metal impact on plants induced the varying intensity of ${ }^{\circ} \mathrm{O}_{2}^{-}$generation in the leaves. So, $10 \mu \mathrm{M}$ of the HM ions (except for $10 \mu \mathrm{M}$ of $\mathrm{Ni}^{2+}$ ) did not change the ${ }^{\circ} \mathrm{O}_{2}{ }^{-}$ generation, but at $1 \mathrm{mM}$ HM in the medium, $\mathrm{Zn}^{2+} \mathrm{or} \mathrm{Pb}^{2+}$ led to an insignificant decrease and $\mathrm{Ni}^{2+}-$ to a slight increase in ${ }^{\circ} \mathrm{O}_{2}^{-}$generation (Table 3).

Table 3. The effect of Ribav-Extra (RE) and heavy metal ions on superoxide $\left({ }^{\cdot} \mathrm{O}_{2}^{-}\right)$generation and on malonic dialdehyde (MDA) content in winter wheat leaves

\begin{tabular}{cccccc}
\hline \multirow{2}{*}{ Treatment } & \multicolumn{2}{c}{$\mathrm{O}_{2}^{-}$generation $\mu \mathrm{M} \mathrm{g}^{-1} \mathrm{~min}^{-1}$} & \multicolumn{2}{c}{ MDA concentration $\mu \mathrm{M} \mathrm{g}^{-1}$} \\
\cline { 3 - 6 } & & without RE & $10 \mathrm{ppm} \mathrm{RE}$ & without RE & $10 \mathrm{ppm} \mathrm{RE}$ \\
\hline \multirow{2}{*}{ Control } & $3.4 \pm 0.4 \mathrm{c}$ & $1.6 \pm 0.1 \mathrm{~b}$ & $0.8 \pm 0.03 \mathrm{c}$ & $0.6 \pm 0.04 \mathrm{ab}$ \\
\hline \multirow{2}{*}{$\mathrm{Cu}$} & $10 \mu \mathrm{M}$ & $3.6 \pm 0.7 \mathrm{~cd}$ & $1.3 \pm 0.03 \mathrm{a}$ & $1.4 \pm 0.1 \mathrm{~d}$ & $0.7 \pm 0.1 \mathrm{bc}$ \\
& $1 \mathrm{mM}$ & $4.3 \pm 0.3 \mathrm{~d}$ & $1.8 \pm 0.3 \mathrm{~b}$ & $2.1 \pm 0.3 \mathrm{e}$ & $0.7 \pm 0.1 \mathrm{bc}$ \\
\hline \multirow{2}{*}{$\mathrm{Ni}$} & $10 \mu \mathrm{M}$ & $4.6 \pm 0.4 \mathrm{~d}$ & $3.2 \pm 0.1 \mathrm{c}$ & $1.3 \pm 0.1 \mathrm{~d}$ & $0.5 \pm 0.03 \mathrm{a}$ \\
& $1 \mathrm{mM}$ & $8.1 \pm 1.0 \mathrm{e}$ & $2.3 \pm 0.3 \mathrm{bc}$ & $1.5 \pm 0.1 \mathrm{~d}$ & $0.9 \pm 0.1 \mathrm{c}$ \\
\hline \multirow{2}{*}{$\mathrm{Pb}$} & $10 \mu \mathrm{M}$ & $2.8 \pm 0.6 \mathrm{bc}$ & $2.0 \pm 0.2 \mathrm{bc}$ & $0.7 \pm 0.1 \mathrm{bc}$ & $0.8 \pm 0.2 \mathrm{abc}$ \\
& $1 \mathrm{mM}$ & $3.0 \pm 0.5 \mathrm{c}$ & $2.0 \pm 0.2 \mathrm{bc}$ & $0.8 \pm 0.1 \mathrm{bc}$ & $0.7 \pm 0.1 \mathrm{bc}$ \\
\hline \multirow{2}{*}{$\mathrm{Zn}$} & $10 \mu \mathrm{M}$ & $3.4 \pm 0.7 \mathrm{~cd}$ & $2.6 \pm 0.7 \mathrm{bc}$ & $0.8 \pm 0.1 \mathrm{bc}$ & $0.6 \pm 0.01 \mathrm{~b}$ \\
& $1 \mathrm{mM}$ & $2.2 \pm 0.3 \mathrm{bc}$ & $1.5 \pm 0.3 \mathrm{ab}$ & $0.7 \pm 0.1 \mathrm{bc}$ & $0.8 \pm 0.1 \mathrm{bc}$ \\
\hline
\end{tabular}

Note. Different letters mean significant differences between variants (separately for ${ }^{\circ} \mathrm{O}_{2}{ }^{-}$generation and for MDA concentration).

Thus, the chronic effect of heavy metals on wheat plants slightly altered the ${ }^{\circ} \mathrm{O}_{2}{ }^{-}$generation in the leaf cells (except for $1 \mathrm{mM}$ of $\mathrm{Cu}^{2+}$ and both $\mathrm{Ni}^{2+}$ treatments). Comparison of the ${ }^{\circ} \mathrm{O}_{2}^{-}$generation rate in wheat leaves with other species (cucumber, maize) showed that this minimal increase in ${ }^{\circ} \mathrm{O}_{2}^{-}$generation is specific to wheat plants. Perhaps this is due to the initial high level of the ROS generation in wheat and lower level in cucumber or maize. Another possible explanation for this is the adaptation of metabolic processes and the normalization in the rate of ROS generation caused by prolonged (within 7 days) plant growth on a medium containing heavy metals. The amount of ${ }^{\circ} \mathrm{O}_{2}^{-}$and $\mathrm{H}_{2} \mathrm{O}_{2}$ on the $3^{\text {rd }}$ day after treatment of wheat plants with $10 \mu \mathrm{M} \mathrm{Ni}^{2+}$ was $250 \%$ compared to the control, but at the $6^{\text {th }}$ and $9^{\text {th }}$ day these parameters decreased (Gajewska, Sklodowska, 2007). Short-term $(2 \mathrm{~h})$ treatment of pea plants with $100 \mu \mathrm{M} \mathrm{CdCl}_{2}$ or $\mathrm{CuSO}_{4}$ resulted in an increase in ${ }^{\circ} \mathrm{O}_{2}{ }^{-}$ generation, followed by its decrease (Lehotai et al., 2011). Obviously, the rapidly changing level of ${ }^{\circ} \mathrm{O}_{2}^{-}$generation can hardly be used as an index for the toxic heavy metals effect in chronic intoxication of wheat seedlings, despite the LPO level.

Seed treatment with Ribav-Extra resulted in a decrease in the ${ }^{\circ} \mathrm{O}_{2}^{-}$level by $54 \%$ relative to the water control (Table 3). In addition, pre-treatment of wheat seeds with Ribav-Extra reduced the rate of ${ }^{\cdot} \mathrm{O}_{2}^{-}$generation in plants exposed to heavy metals, especially at $\mathrm{Cu}^{2+}$ (by $60-65 \%$ ) and $1 \mathrm{mM} \mathrm{Zn}^{2+}$ (by 56\%) treatments. Under the action $\mathrm{Pb}^{2+}$, the effectiveness of Ribav-Extra was less expressed (there was only insignificant decrease in the rate of $\mathrm{O}_{2}^{-}$generation relative to untreated plants). Heavy metals influenced differently the LPO intensity in the wheat leaves in different variants of the experiment (Table 3). The maximum MDA concentration was detected at concentrations of $10 \mu \mathrm{M}$ and $1 \mathrm{mM}$ under the impact of $\mathrm{Cu}^{2+}(164 \%$ and $256 \%$, respectively, compared to water control) or $\mathrm{Ni}^{2+}$ (1.5 and 1.7 times, respectively, above the control). $\mathrm{Pb}^{2+}$ and $\mathrm{Zn}^{2+}$ did not significantly change the amount of MDA in the leaves relative to the water control.

It is known that heavy metals can induce oxidative stress (Hossain et al., 2012; Rahoui et al.,
2017; Thakur et al., 2017), thereby significantly affecting the processes of LPO, leading to the destruction of cell membranes; the rate of their damage can be assessed from the accumulation of MDA (Lukatkin et al., 2010). However, in the study we found that MDA accumulation in wheat leaves was significantly dependent on the metal and much less on its concentration in the medium. The level of LPO intensity was significantly higher in $\mathrm{Cu}^{2+}$ or $\mathrm{Ni}^{2+}$-treated seedlings (both concentrations), but it was invariable in $\mathrm{Pb}^{2+}-$ or $\mathrm{Zn}^{2+}$-treated plants. At the same time, differences in MDA accumulation between variants with suboptimal and sub-lethal concentrations of heavy metals in the medium were not always significant. The increase in the content of LPO products in wheat leaves affected by $\mathrm{Ni}$ and $\mathrm{Cu}$ ions indicates significant damage to membrane lipids. This can cause alterations in the membranes permeability, inhibition of membrane enzymes, and leads to the changes in cytoplasm ion balance (Anjum et al., 2015 b).

It is known that plant hormones intensively interact with ROS, thus alleviate the stress reaction of plants (Gangwar et al., 2014; Xia et al., 2015). Pretreatment of wheat seeds with Ribav-Extra contributed to a decrease in the intensity of lipid peroxidation in plant leaves (Table 3). Comparison of RE-treated and RE-untreated plants showed that a significant decrease in the LPO intensity in the treatments at $10 \mu \mathrm{M}$ and 1 mM with $\mathrm{Cu}^{2+}$ (by $36 \%$ and $70 \%$, respectively) or $\mathrm{Ni}^{2+}$ (by $60 \%$ and $39 \%$, respectively). In other treatments at both concentrations of $\mathrm{Zn}^{2+}$ and $\mathrm{Pb}^{2+}$, Ribav-Extra effect on LPO intensity in the wheat leaves was insignificant.

The influence of heavy metal ions and RibavExtra on the activity of enzymatic antioxidants. A special role in the protective reactions of plants to the heavy metals action belongs to enzymatic antioxidants, whose activity increases significantly under these conditions (Hossain et al., 2012; Rahoui et al., 2017; Thakur et al., 2017). This leads to neutralization of ROS, which are formed in heavy metal-treated plants and have a damaging effect on the cells, and to increased resistance to heavy metals in plants.

Calatase (CAT) activity. One of the main enzymatic antioxidants in plants is CAT, which utilizes 
$\mathrm{H}_{2} \mathrm{O}_{2}$ excess, formed during ROS metabolism (Lukatkin, 2002 b; Mittler, 2002; Anjum et al., 2016). The activity of CAT in wheat leaves increased compared to the control in all heavy metal treatments, except for $10 \mu \mathrm{M} \mathrm{Ni}^{2+}$ (Table 4). The maximum CAT activity was induced at $10 \mu \mathrm{M}$ and $1 \mathrm{mM}$ by $\mathrm{Cu}^{2+}(225 \%$ and $166 \%$, respectively, compared to water control) and $\mathrm{Pb}^{2+}(227 \%$ and $164 \%$, respectively, compared to water control). Since CAT is an inducible enzyme (its activity increases when the substrate $\left(\mathrm{H}_{2} \mathrm{O}_{2}\right)$ amount rises in the medium), an increase in its activity in the presence of heavy metals indicates intensification in the ROS generation in wheat seedlings cells. CAT activity was significantly higher at $10 \mu \mathrm{M}$ of $\mathrm{Cu}^{2+}$ or $\mathrm{Pb}^{2+}$ and at $1 \mathrm{mM}$ of $\mathrm{Zn}^{2+}$ or $\mathrm{Ni}^{2+}$. Probably, this reflected the differences in the metabolic pathways of ROS utilization under the metal action. Pre-sowing treatment of wheat seeds with Ribav-Extra promoted a decrease in CAT activity by $26 \%$ relative to water control (Table 4). In the HM-containing medium, RE-pretreatment did not change the CAT activity relative to the untreated plants, except for the following cases: in leaves of RE-treated plants, the enzyme activity decreased by $15 \%$ and $21 \%$ at $10 \mu \mathrm{M}$ and $1 \mathrm{mM}$ of $\mathrm{Ni}^{2+}$, respectively, and by $10 \%$ at $10 \mu \mathrm{M}$ of $\mathrm{Zn}^{2+}$.

Table 4. The influence of Ribav-Extra (RE) on catalase (CAT) and ascorbate peroxidase (APOX) activities $\left(\mu \mathrm{M} \mathrm{g}^{-1} \mathrm{~min}^{-1}\right)$ in winter wheat plants treated with heavy metal ions

\begin{tabular}{cccccc}
\hline \multirow{2}{*}{ Treatment } & \multicolumn{2}{c}{ Catalase } & \multicolumn{2}{c}{ Ascorbate peroxidase } \\
\cline { 3 - 6 } & & without RE & $10 \mathrm{ppm} \mathrm{RE}$ & without RE & $10 \mathrm{ppm} \mathrm{RE}$ \\
\hline \multicolumn{2}{c}{ Control } & $14.9 \pm 0.9 \mathrm{bc}$ & $11.1 \pm 0.2 \mathrm{a}$ & $0.5 \pm 0.1 \mathrm{ab}$ & $0.2 \pm 0.1 \mathrm{a}$ \\
\hline \multirow{2}{*}{$\mathrm{Cu}$} & $10 \mu \mathrm{M}$ & $33.4 \pm 1.9 \mathrm{f}$ & $34.5 \pm 1.5 \mathrm{f}$ & $0.3 \pm 0.1 \mathrm{ab}$ & $0.5 \pm 0.1 \mathrm{ab}$ \\
& $1 \mathrm{mM}$ & $24.7 \pm 1.6 \mathrm{de}$ & $23.1 \pm 0.7 \mathrm{de}$ & $0.3 \pm 0.1 \mathrm{ab}$ & $0.3 \pm 0.1 \mathrm{ab}$ \\
\hline \multirow{2}{*}{$\mathrm{Ni}$} & $10 \mu \mathrm{M}$ & $15.3 \pm 0.7 \mathrm{c}$ & $13.0 \pm 0.5 \mathrm{~b}$ & $0.5 \pm 0.04 \mathrm{~b}$ & $0.5 \pm 0.1 \mathrm{ab}$ \\
& $1 \mathrm{mM}$ & $27.5 \pm 1.9 \mathrm{e}$ & $21.8 \pm 0.2 \mathrm{~d}$ & $0.4 \pm 0.1 \mathrm{ab}$ & $0.5 \pm 0.1 \mathrm{ab}$ \\
\hline \multirow{2}{*}{$\mathrm{Pb}$} & $10 \mu \mathrm{M}$ & $32.2 \pm 0.8 \mathrm{f}$ & $33.0 \pm 0.4 \mathrm{f}$ & $0.5 \pm 0.1 \mathrm{ab}$ & $0.3 \pm 0.03 \mathrm{a}$ \\
& $1 \mathrm{mM}$ & $24.4 \pm 0.9 \mathrm{de}$ & $21.6 \pm 0.3 \mathrm{~d}$ & $0.3 \pm 0.1 \mathrm{ab}$ & $0.2 \pm 0.1 \mathrm{ab}$ \\
\hline \multirow{2}{*}{$\mathrm{Zn}$} & $10 \mu \mathrm{M}$ & $24.4 \pm 0.7 \mathrm{e}$ & $21.9 \pm 0.2 \mathrm{~d}$ & $0.4 \pm 0.04 \mathrm{ab}$ & $0.2 \pm 0.1 \mathrm{ab}$ \\
& $1 \mathrm{mM}$ & $33.2 \pm 1.1 \mathrm{f}$ & $31.9 \pm 0.3 \mathrm{f}$ & $0.5 \pm 0.1 \mathrm{ab}$ & $0.2 \pm 0.1 \mathrm{ab}$ \\
\hline
\end{tabular}

Note. Different letters mean significant differences between variants (separately for CAT and for APOX).

Ascorbate peroxidase (APOX) activity. In the experiment, we demonstrated the influence of heavy metals on the activity of APOX in wheat leaves. APOX is the main enzyme that utilizes $\mathrm{H}_{2} \mathrm{O}_{2}$ in plants. An increase in the activity of APOX may perhaps indicate an increase in the synthesis of APOX isoenzymes, which reduce the concentration of $\mathrm{H}_{2} \mathrm{O}_{2}$ and protect against oxidative stress (Anjum et al., 2016). In our experiments, the activity of APOX was at the control level at all the heavy metals studied (Table 4). We showed that RE-pretreated plants had lower APOX activity in comparison to untreated ones in a medium containing $\mathrm{Pb}$ or $\mathrm{Zn}$ ions but it insignificantly increased in the presence of $\mathrm{Cu}$ or $\mathrm{Ni}$.

\section{Conclusions}

1. Heavy metals (HM) in growth media lead to oxidative stress in winter wheat (Triticum aestivum L.) seedlings. By toxicity level to wheat seedlings, the heavy metals can be arranged in the following order: $\mathrm{Zn} \leq \mathrm{Pb}<<\mathrm{Cu}<\mathrm{Ni}$. There were no significant differences between essential $(\mathrm{Zn}$ and $\mathrm{Ni})$ and non-essential $(\mathrm{Pb})$ heavy metals influence on superoxide $\left(\mathrm{O}_{2}^{-}\right)$generation in wheat leaves. The increase in lipid peroxidation (LPO) products in $\mathrm{Cu}^{2+}$ - and $\mathrm{Ni}^{2+}$-treated plants may be evidence of serious damage in membrane lipids induced by heavy metals. Heavy metal ions induced enhanced catalase (CAT) activity, too.

2. Ribav-Extra (RE) stimulated growth of roots and shoots (except for $1 \mathrm{mM}$ of $\mathrm{Cu}^{2+}$ ) in HM-treated wheat plants and significantly reduced the heavy metals accumulation in wheat seedlings exposed to $\mathrm{Cu}^{2+}$ or $1 \mathrm{mM}^{2} \mathrm{~Pb}^{2+}$ (in roots) and to $10 \mu \mathrm{M}$ of $\mathrm{Cu}^{2+}$ or $1 \mathrm{mM}$ of $\mathrm{Ni}^{2+}$ (in shoots). Also, Ribav-Extra treatment promoted $\mathrm{Cu}^{2+}$ translocation in shoots and inhibited the $\mathrm{Ni}^{2+}$ translocation.
3. Ribav-Extra showed the opposite effect on heavy metals action, lead to partial reduction of ${ }^{\circ} \mathrm{O}_{2}{ }^{-}$ generation in wheat leaves, most effectively in $\mathrm{Cu}^{2+}$ treated plants as well as to a decrease of LPO intensity and CAT activity. The maximal effectivity of REtreatment was noted in the case of $\mathrm{Cu}^{2+}$ and $\mathrm{Ni}^{2+}$ action.

Received 05102017 Accepted 04052018

\section{References}

1. Ali E., Maodzeka A., Hussain N., Shamsi I. H., Jiang L. 2015. The alleviation of cadmium toxicity in oilseed rape (Brassica napus) by the application of salicylic acid. Plant Growth Regulation, 75 (3): 641-655. https://doi.org/10.1007/s10725-014-9966-0

2. Anjum N. A., Umar S., Ahmad A. 2012. Oxidative stress in plants. Causes, consequences and tolerance. New Delhi, India, $545 \mathrm{p}$.

3. Anjum N. A., Singh H. P., Khan M. I., Masood A., Per T., Negi A., Batish D., Khan N. A., Duarte A. C., Pereira E. 2015 (a). Too much is bad - an appraisal of phytotoxicity of elevated plant-beneficial heavy metal ions. Environmental Science and Pollution Research, 22: 3361-3382. https://doi.org/10.1007/s11356-014-3849-9

4. Anjum N. A., Sofo A., Scopa A., Roychoudhury A., Gill S. S., Iqbal M., Lukatkin A. S., Pereira E., Duarte A. C., Ahmad I. 2015 (b). Lipids and proteins major targets of oxidative modifications in abiotic stressed plants. Environmental Science and Pollution Research, 22 (6): 4099-4121. https://doi.org/10.1007/s11356-014-3917-1

5. Anjum N. A., Sharma P., Gill S. S., Hasanuzzaman M., Khan E. A., Mohamed A. A., Kachhap K., Thangavel P., Devi G. D., Vasudhevan P., Sofo A., Khan N. A., Misra A. N., Lukatkin A. S., Singh H. P., Pereira E., Tuteja N. 2016. Catalase and ascorbate peroxidase - 
representative $\mathrm{H}_{2} \mathrm{O}_{2}$-detoxifying haeme enzymes in plants. Environmental Science and Pollution Research, 23 (19): 19002-19029.

https://doi.org/10.1007/s11356-016-7309-6

6. Asgher M., Khan M. I. R., Anjum N. A., Khan N. A. 2015. Minimizing toxicity of cadmium in plants - role of plant growth regulators. Protoplasma, 252: 399-413.

https://doi.org/10.1007/s00709-014-0710-4

7. Bashmakov D. I., Pynenkova N. A., Sazanova K. A. Lukatkin A. S. 2012. Effects of the synthetic growth regulator Cytodef and heavy metals on oxidative status in cucumber plants. Russian Journal of Plant Physiology, 59 (1): $57-62$.

https://doi.org/10.1134/S1021443712010049

8. Bashmakov D. I., Lukatkin A. S., Anjum N. A., Ahmad I., Pereira E. 2015. Evaluation of zinc accumulation, allocation, and tolerance in Zea mays L. seedlings: implication for zinc phytoextraction. Environmental Science and Pollution Research, 22 (20): 15443-15448.

https://doi.org/10.1007/s11356-015-4698-x

9. Bashmakov D. I., Gruznova K. A., Lukatkin A. S., Anjum N. A., Pereira E. 2016. Assessment of divalent metal-toxicity and the role of 24-epibrassinolide in Triticum aestivum seedlings. Aperito Journal of Advanced Plant Biology, 2 (1): 107.

https://doi.org/10.14437/2381-4993-2-107

10. Duchovskis P., Brazaityte A., Juknys R., Januškaitienė I., Sliesaravičius A., Ramaškevičienè A., Burbulis N., Šikšnianienè J. B., Baranauskis K., Duchovskienė L., Stanys V., Bobinas Č. 2006. Changes of physiological and genetic indices of Lycopersicon esculentum Mill. by cadmium under different acidicity and nutrition. Polish Journal of Environmental Studies, 15 (2): 235-242.

11. Fariduddin Q., Radium R. A., Khalil E., Mir B. A., Yusuf M., Ahmad A. 2013. 24-Epibrassinolide regulates photocynthesis, antioxidant enzyme activities and proline content in Cucumis sativus under salt and/or copper stress. Environmental Monitoring and Assessment, 185 (9): 7845-7856.

https://doi.org/10.1007/s10661-013-3139-x

12. Gajewska E., Sklodowska M. 2007. Effect of nickel on ROS content and antioxidative enzyme activities in wheat leaves. BioMetals, 20: 27-36.

https://doi.org/10.1007/s10534-006-9011-5

13. Gangwar S., Singh V. P., Srivastava P. K., Maurya J. N. 2011 (a). Modification of chromium (VI) phytotoxicity by exogenous gibberellic acid application in Pisum sativum (L.) seedlings. Acta Physiologiae Plantarum, 33 (4): 1385-1397.

https://doi.org/10.1007/s11738-010-0672-x

14. Gangwar S., Singh V. P., Prasad S. M., Maurya J. N. 2011 (b). Differential responses of pea seedlings to indole acetic acid under manganese toxicity. Acta Physiologiae Plantarum, 33 (2): 451-462. https://doi.org/10.1007/s11738-010-0565-z

15. Gangwar S., Singh V. P., Tripathi D. K., Chauhan D. K., Prasad Sh. M., Maurya J. N. 2014. Plant responses to metal stress: the emerging role of plant growth hormones in toxicity alleviation. Ahmad P., Rasool S. (eds). Emerging technologies and management of crop stress tolerance, 2: $215-248$.

https://doi.org/10.1016/B978-0-12-800875-1.00010-7

16. Gruznova K. A., Bashmakov D. I., Brazaityte A., Duchovskis P., Lukatkin A. S. 2017. Efficiency index as the integral indicator of Triticum aestivum response to growth regulators. Zemdirbyste-Agricultire, 104 (4): 299-304. https://doi.org/10.13080/z-a.2017.104.038

17. Hayat S., Khalique G., Wani A. Sh., Alyemeni M. N., Ahmed A. 2014. Protection of growth in response to 28-homobrassinolide under the stress of cadmium and salinity in wheat. International Journal of Biological Macromolecules, 64: 130-136.

https://doi.org/10.1016/j.ijbiomac.2013.11.021
18. Hossain M. A., Piyatida P., Teixeira da Silva J. A., Fujita M. 2012. Molecular mechanism of heavy metal toxicity and tolerance in plants: central role of glutathione in detoxification of reactive oxygen species and methylglyoxal and in heavy metal chelation. Journal of Botany, 2012: 872-875. https://doi.org/10.1155/2012/872875

19. Hussain I., Siddique A., Ashraf M. A., Rasheed R., Ibrahim M., Iqbal M., Akbar S., Imran M. 2017. Does exogenous application of ascorbic acid modulate growth, photosynthetic pigments and oxidative defense in okra (Abelmoschus esculentus (L.) Moench) under lead stress? Acta Physiologiae Plantarum, 39: 144. https://doi.org/10.1007/s11738-017-2439-0

20. Lazauskas S., Povilaitis, V., Antanaitis Š., Sakalauskaitė J., Sakalauskienė S. Pšibišauskienė G., Auškalnienè O., Raudonius S., Duchovskis P. 2012. Winter wheat leaf area index under low and moderate input management and climate change. Journal of Food, Agriculture and Environment, 10 (1): 588-593.

21. Lehotai N., Petö A., Bajkán Sz., Erdei L., Tari I., Kolbert Z. 2011. In vivo and in situ visualization of early physiological events induced by heavy metals in pea root meristem. Acta Physiologiae Plantarum, 33 (6): 2199-2207. https://doi.org/10.1007/s11738-011-0759-z

22. Lukatkin A. S. 2002 (a). Contribution of oxidative stress to the development of cold-induced damage to leaves of chilling-sensitive plants. 1. Reactive oxygen species formation during plant chilling. Russian Journal of Plant Physiology, 49 (5): 622-627.

23. Lukatkin A. S. 2002 (b). Contribution of oxidative stress to the development of cold-induced damage to leaves of chilling-sensitive plants. 2. The activity of antioxidant enzymes during plant chilling. Russian Journal of Plant Physiology, 49 (6): 782-788. https://doi.org/10.1023/A:1020965629243

24. Lukatkin A. S., Kistenjova T. E., Teixeira da Silva J. A. 2010. Oxidative stress in cucumber (Cucumis sativus L.) leaf cells: short-term influence of heavy metals (lead and copper). Plant Stress, 4 (1): 44-49.

25. Lukatkin A. S., Pogodina D. N. 2012. Efficacy of the protective action of growth regulator Ribav-Extra on maize seedlings under temperature stress. Russian Agricultural Sciences, 38 (2): 94-97. https://oi.org/10.3103/S1068367412020140

26. Miliauskienè J., Sakalauskienė S., Lazauskas S., Povilaitis V., Brazaitytè A., Duchovskis P. 2016. The competition between winter rape $\left(\mathrm{C}_{3}\right)$ and maize $\left(\mathrm{C}_{4}\right)$ plants in response to elevated carbon dioxide and temperature, and drought stress. Zemdirbyste-Agriculture, 103 (1): 21-28. https://doi.org/10.13080/z-a.2016.103.003

27. Mittler R. 2002. Oxidative stress, antioxidants and stress tolerance. Trends in Plant Science, 7 (1): 405-410. https://doi.org/10.1016/S1360-1385(02)02312-9

28. Rahoui S., Martinez Y., Sakouhi L., Ben C., Rickauer M., El Ferjani E., Gentzbittel L., Chaoui A. 2017. Cadmiuminduced changes in antioxidative systems and differentiation in roots of contrasted Medicago truncatula lines. Protoplasma, 254 (1): 473-489. https://doi.org/10.1007/s00709-016-0968-9

29. Sakalauskienė S., Karklelienė R., Radzevičius A., Bobinas C., Brazaitytè A., Sakalauskaitè J., Viškelis P., Samuolienė G., Duchovskis P., Pinikienė J. 2012. Effect of Ocimum basilicum L. biological preparation on tomato fruit quality grown in greenhouse. Acta Horticulturae, 952: 821-825.

https://doi.org/10.17660/ActaHortic.2012.952.104

30. Sazanova K. A., Bashmakov D. I., Brazaitytė A., Bobinas Č., Duchovskis P., Lukatkin A. S. 2012. The effect of heavy metals and thidiazuron on winter wheat (Triticum aestivum L.) seedlings. Zemdirbyste-Agriculture, 99 (3): 273-278. 
31. Seregin I. V., Kozhevnikova A. D. 2008. Roles of root and shoot tissues in transport and accumulation of cadmium, lead, nickel, and strontium. Russian Journal of Plant Physiology, 55 (1): 1-22. https://doi.org/10.1134/S1021443708010019

32. Sharma P., Sheikh I., Singh D., Kumar S., Verma S. K., Kumar R., Vyas P., Dhaliwal H. S. 2017. Uptake, distribution, and remobilization of iron and zinc among various tissues of wheat - Aegilops substitution lines at different growth stages. Acta Physiologiae Plantarum, 39: 185. https://doi.org/10.1007/s11738-017-2456-z

33. Singh I., Shah K. 2014. Exogenous application of methyl jasmonate lowers the effect of cadmium-induced oxidative injury in rice seedlings. Phytochemistry, 108: 57-66. https://doi.org/10.1016/j.phytochem.2014.09.007

34. Singh S., Parihar P., Singh R., Singh V. P., Prasad S. M. 2016. Heavy metal tolerance in plants: role of transcriptomics, proteomics, metabolomics, and ionomics. Frontiers in Plant Science, 6: 1143.

https://doi.org/10.3389/fpls.2015.01143

35. Thakur S., Singh L., Zularisam A. W., Sakinah M., Din M.F.M. 2017. Lead induced oxidative stress and alteration in the activities of antioxidative enzymes in rice shoots. Biologia Plantarum, 61 (3): 595-598. https://doi.org/10.1007/s10535-016-0680-9

36. Wilkins D. A. 1978. The measurement of tolerance to edaphic factors by means of root growth. New Phytologist, 80: 623-633.

https://doi.org/10.1111/j.1469-8137.1978.tb01595.x

37. Xia X.-J., Zhou Y.-H., Shi K., Zhou J., Foyer C. H., Yu J.-Q. 2015. Interplay between reactive oxygen species and hormones in the control of plant development and stress tolerance. Journal of Experimental Botany, 66 (10): 2839-2856.

https://doi.org/10.1093/jxb/erv089
38. Zhang F., Zhang H., Xia Y., Wang G., Xu L., Shen Z. 2011. Exogenous application of salicylic acid alleviates cadmium toxicity and reduces hydrogen peroxide accumulation in root apoplasts of Phaseolus aureus and Vicia sativa. Plant Cell Reports, 30 (8): 1475-1483.

https://doi.org/10.1007/s00299-011-1056-4

39. Zhu X. F., Wang Z. W., Dong F., Lei G. J. Shi Y. Z., Li G. X., Zheng S. J. 2013. Exogenous auxin alleviates cadmium toxicity in Arabidopsis thaliana by stimulating synthesis of hemicellulose 1 and increasing the cadmium fixation capacity of root cell walls. Journal of Hazardous Materials, 263: 398-403. https://doi.org/10.1016/j.jhazmat.2013.09.018

40. Башмаков Д. И., Лукаткин А. С. 2009. Экологофизиологические аспекты аккумуляции и распределения тяжелых металлов у высших растений. Саранск, 236 c. (in Russian).

41. Рязин Э. Н., Михеева Т. Г., Толмачева Н. А., Орловский Д. Д. 2005. Новый регулятор роста растений рибав-экстра. Средства защиты растений, регуляторы роста, агрохимикаты и их применение при возделывании сельскохозяйственных культур. Москва, c. 56-58 (in Russian).

42. Толмачева Н. А., Михеева Т. Г. 2008. Регулятор роста растений «Рибав-Экстра». Современные технологии и перспективы использования средств защиты растений, регуляторов роста, агрохимикатов в агроландшафтном земледелии. Москва, с. 123-127 (in Russian).

\title{
Augimo reguliatoriaus Ribav-Extra įtaka sunkiaisiais metalais paveiktų žieminių kviečių daigams
}

\author{
K. A. Gruznova ${ }^{1}$, D. I. Bashmakov ${ }^{1}$, J. Miliauskiené2, V. Vaštakaité丶 \\ P. Duchovskis ${ }^{2,3}$, A. S. Lukatkin ${ }^{1}$ \\ ${ }^{1}$ Mordovijos valstybinis universitetas, Rusija \\ ${ }^{2}$ Lietuvos agrarinių ir miškų mokslų centro Sodininkystès ir daržininkystès institutas \\ ${ }^{3}$ Aleksandro Stulginskio universitetas
}

\section{Santrauka}

Tirta natūralaus augimo reguliatoriaus Ribav-Extra ir sunkiujų metalų (SM) jonų $-\mathrm{Pb}^{2+}, \mathrm{Cu}^{2+}, \mathrm{Zn}^{2+}$, bei Ni ${ }^{2+}-$ įtaka žieminio kviečio (Triticum aestivum L.) veislès 'Mironovskaya 808' fiziologiniams ir biocheminiams rodikliams. Žieminių kviečių sèklos buvo paveiktos Ribav-Extra (10 ppm) ir 7 dienas augo sunkiųų metalų druskų tirpaluose $(10 \mu \mathrm{M}$ arba $1 \mathrm{mM})$, po to ivvertintas sunkiujų metalu kaupimasis augaluose, augalų augimas, superoksido anijonų $\left({ }^{\circ} \mathrm{O}_{2}^{-}\right)$gamyba, lipidų peroksidacija, katalazès ir askorbato peroksidazès aktyvumas. Nustatyta, kad $1 \mathrm{mM} \mathrm{SM}$ tirpalas augimo terpejje padidino sunkiujų metalų kaupimąsi žieminiuose kviečiuose ir slopino šaknų bei ūglių augimą. Ir mažos, ir didelès sunkiujų metalų koncentracijos kviečių daiguose paskatino ${ }^{\circ} \mathrm{O}_{2}^{-}$gamybą ir sukèlè oksidacinius pažeidimus. Beveik visų variantų augaluose sunkiūų metalų toksinis poveikis sustiprèjo esant didesnèms koncentracijoms. Sẻklų apdorojimas Ribav-Extra prieš sèją mažino sunkiujų metalų poveiki žieminių kviečių daigams, slopino jų sukeltą oksidacinį stresą, mažino ${ }^{\circ} \mathrm{O}_{2}^{-}$gamybą, lipidų peroksidacijos intensyvumą ir katalazès aktyvumą. Tai rodo, kad sunkiụjų metalų poveikiui buvo atsparesni augimo reguliatoriumi Ribav-Extra apdoroti žieminių kviečių daigai nei neapdoroti. 